\begin{tabular}{lllllll}
\hline ISSN & $0258-2279$ & Literator & 8 & $(1987)$ & no. & 3 \\
\hline
\end{tabular}

\title{
M.J. Mans
}

\section{The utilization of space in Martial $\mathbf{1 . 8 6}^{1}$}

\begin{abstract}
This article examines the form and function of space in Martial's epigram 1.86. It comments on the important aspect of verbal creation of space, i.e. the concept of selectivity, which results in an incomplete description of space. It is demonstrated, however, that the reader, with the aid of spatial indicators in the text, is able to fill in the spatial gaps. With the support of these indicators an attempt is made to determine whether space is given special prominence in 1.86. The horizontal dimension of space, i.e. the concept of the binary opposition far vs. near is delineated as an important and special implement in the hands of the poet to convey the poem's message. The narrator's point of view, or focalization, is also touched upon.

In conclusion the predominant theme in this epigram, i.e. space, is defined as lyric space. It is argued that space can be exploited in different ways so as to convey meaning through it, and thus contributes towards a better understanding of the poem.
\end{abstract}

Man and his existence are inseparably interwoven with space and time. Today, more than ever before, man is enthralled by the interwinement which has held his attention for many ages. As a being whose existence is connected with space and time, man's essential orientation makes it virtually impossible for him to come to terms with the concept of spacelessness/timelessness. Man's experience of reality is therefore inextricably linked to the spatiality of phenomena, space being one of man's most important categories of percep-

1. I am indebted to my colleague, professor J.H. Barkhuizen, for some useful suggestions. 
tion (Cloete et al., 1985:168). This is also applicable to literature (Venter, 1985:19).

This fundamental association between space on the one hand, and human existence and thought on the other (Lotman, 1972:312), is crucially relevant when discussing space in a literary text in general, and in the poetry of Martial or of any other poet in particular. Just as in the case of man, space is a prerequisite for the existence of persons, events, time, places and objects on paper (Venter, 1985:19). We must, of course, bear in mind that the four categories of space, time, events and persons occur, though differently, in all three of the main genres, drama, epic and lyric. Although space is usually neglected in favour of events, persons and time, it can be just as formative and significant to the structure and meaning of a poem as the other three categories mentioned (Venter, 1985:19-20). Therefore the analysis of space in a poem can contribute significantly to an understanding of its message (Cloete et al., 1985:169).

Consequently the aim of this study will be to examine the form and function of space (Zoran, 1984:320-321, 322-323, 316-317) in Martial's epigram 1.86 .

Space in a written text can only be created verbally. An important aspect of this verbal creation of space, however, is the concept of selectivity. This selectivity expresses some things in a concrete way, others vaguely or generally, and may ignore others altogether, i.e. there is no complete description of space (Zoran, 1984:320). For instance, 'vicinus ('neighbour') . . . manuque tangi ('(can be) touched with the hand')' line 1 , and 'de nostris ... fenestris' ('from my window(s)') line 2, all rather incompletely express space. But, although incomplete, spatial indicators in a text are sufficient for the reader to fill in the spatial gaps, i.e. to construct in his mind a fuller picture of the space which the text is presenting (Perry and Sternberg, 1986:275-283; Sternberg, 1985:186ff.; Venter, 1985:26). Consequently, although there are many gaps in the information about space in this poem, it is not essential to fill them all, e.g. the nature and size of the rooms, their height above street level, or the furniture in them (how many pieces of furniture, etc.), where exactly these rooms are situated, the exact distance between the poet and Novius etc. etc. ${ }^{2}$

In an attempt to determine whether space is given special prominence in 1.86 , we must first search for verbal indicators of space. From the quantity of the explicit and implicit denominators to be indicated below, one is justified in inferring that spatiality in this particular poem is a value in its own right. Moreover, it will become evident from the structuring of the line of thought

2. Cf. Zoran, 1984:320. The only 'direct' information given about their to pographical situation is 'urbe', the traditional and well-known reference to Rome (line 9). 
in 1.86 that space is undoubtedly utilized by the poet as an explicit situation constructor, i.e. the poem is space-orientated (Cloete et al., 1985:169; Zoran, 1984:314).

In the diagram below are the text, a translation, and the structuring of the line of thought. The framed-in words or phrases in the text indicate the spatial dimensions in this poem:

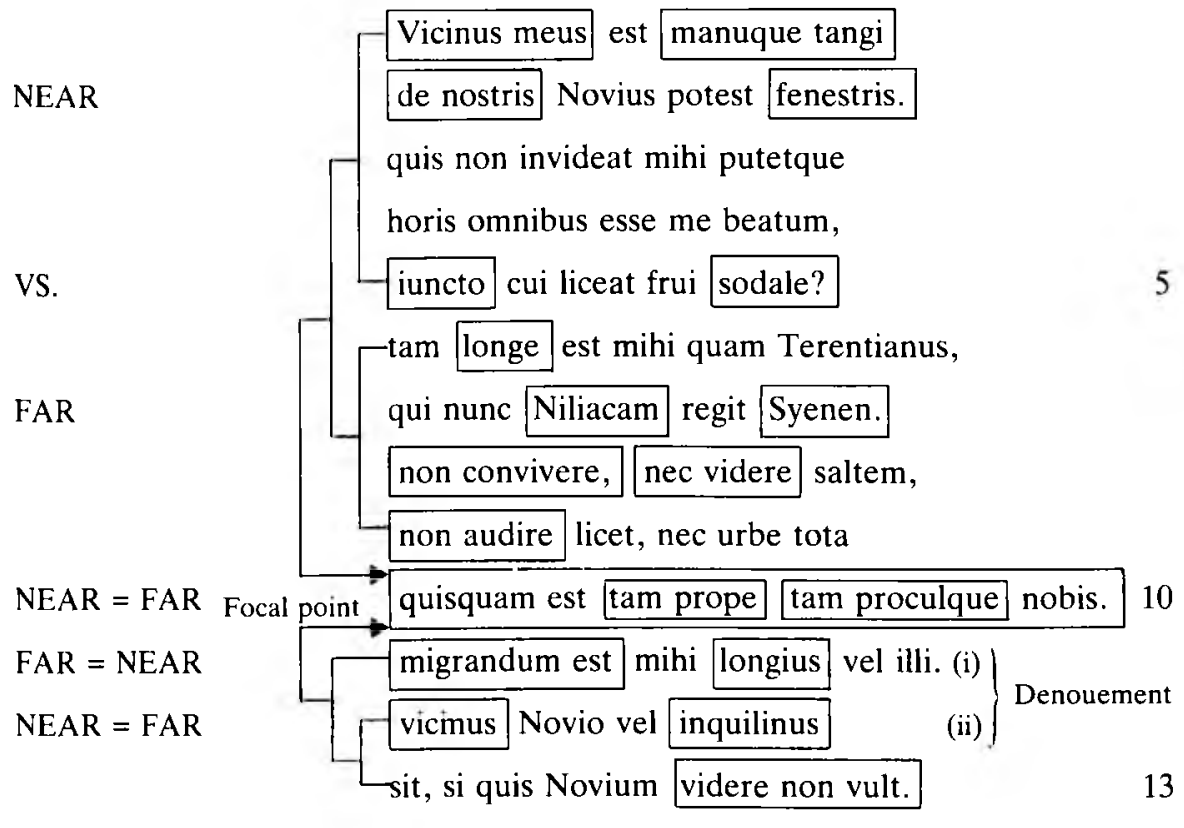

Mart. Epigram. 1.86

\section{Translation}

Novius is my neighbour, and can be touched with the hand from my window(s).

Who would not envy me, and think that I was

happy at every hour of the day,

since I am able to have the benefit of a companion close

at hand?

He is as far away from me as is Terentianus, who now commands Syene on the Nile.

I may neither share my life/feast with him, nor even see him, or hear him, nor is there anyone in the whole city

so close and yet so far away from me.

Either I or he must move further away.

Let anyone who does not wish to see Novius

be his neighbour or fellow-tenant. 
The order of thought is structured as follows:

A 1-5: Nearness of Novius: 1-2:

3-5: Result: everyone envies the poet his "privilege" and favourable position.
B 6-10: Reality:
$6-7$
Statement: Novius may just as well be in Egypt.
8-10: Reason: there is no personal, social contact with Novius.
C 11-13: Denouement: 11:
Solution: either Novius or the poet must move further away (in order to see each other more often!)
12-13: Sting: you must be with Novius to lose contact with him.

Two obvious, but rather significant clues occur in the very first line: the first word in the epigram, 'Vicinus', referring to the poet's neighbour next-door or across the presumably narrow street, ${ }^{3}$ and the expressive 'manuque tangi', suggesting nearness because he can touch his neighbour with the hand. This is followed by certainly one of his most important spatial orientations in the whole poem: 'de nostris . . . fenestris' ('from my window(s)'), line 2, the literary implication of which will be discussed later on. The spatiality, nearness, which is dealt with as a unit in lines $1-5$, is concluded in line 5 by the words 'iuncto ... sodale' ('(the benefit of) a companion close at hand'). Another set of indicators refers explicitly to the spatial remoteness in lines 6-9, presented as a unit, by means of the following verbal indicators: in line 6 the obvious 'longe' ('far away'), in line 7 'Niliacam . . . Syenen' ('Syene on the Nile'). ${ }^{4}$ The concept of remoteness can also be inferred from the implicit phrases 'non convivere' ('neither share my life/feast with him', 'nec videre' ('nor even see him') line 8, and 'non audire' ('or hear him') line 9. In line 10 near and far are placed in opposition to each other: 'tam prope' ('so close') vs. 'tam procul' ('so far away'). Finally, space is created in the last three lines by 'migrandum est . . . longius' ('. . . must move further away') line ", 'vicinus ('neighbour') . . . inquilinus' ('fellow-tenant') line 12, and 'videre non vult' ('(who) does not wish to see (Novius)'), line 13.

3. Howell. 1980:290-291: 'Since the point of the epigram lies in the paradox, perhaps one should not enquire too closely into the question of why in fact the two neighbours see so little of each other. But the obvious reason would seem to be that attested by modern sociological studies of flat-dwellers, namely, the natural desire of people forced by circumstances into living at excessively close quarters to keep their independence and not involve themselves in each other's lives. Compare, for example, the remark made by a resident of Quarry Hill Flats, Leeds, "I've got a lovely neighbour: I never see her" (Alison Ravetz, Model Estate, (1974) 176).' Howell also points out that the poet and Novius are presumably living in 'cenacula' on the upper floors of 'insulae' on opposite sides of the street. Alternatively, however, their windows might be side by side.

4. Howell, 1980:290-291: referring to modern Aswan, which until the reign of Trajan formed the southernmost outpost of the Roman Empire. 
From the above it is clear that the concept of the binary opposition (far vs. near, i.e. a horizontal dimension of space) is an important instrument to convey the poem's message (Zoran, 1984:316).

On closer examination of the line of thought in this poem it strikes one that whereas 'Vicinus' in line 1 implies the spatial concept nearness, and is supported and confirmed by 'manuque tangi', 'de nostris . . . fenestris', and 'iuncto . . . sodale', we find that 'vicinus' and 'inquilinus', in line 12 , seen through the ironic eyes of the narrator, mean exactly the opposite, i.e. far, as can be deduced from 'videre non vult' (line 13). This very first word in the first line of the epigram, 'vicinus', is therefore contrasted with the last three words, 'videre non vult'.

Whereas initially, in lines $1-9$, the poet sets near and far (let's say a vs. b) in opposition, so as to show their striking difference, he subsequently places these two conflicting spatialities in the form of a synthesis, next to each other in line 10. But in doing so, as paradoxical as it may sound, he equalizes them: 'prope' ('near'), i.e. a, = 'procul' ('far'), i.e. b (line 10). Then the poet extends this paradoxical equalization of these two divergent spatial poles to a final climax in lines 11-13: in other words, with 'migrandum est mihi vel illi' ('Either I or he must move further away'), line 11, is implied that far = near, i.e. the further away you are from Novius the nearer you are to him: b, i.e. 'procul' (suggested by 'longius' ('further away') = a, i.e. 'prope' (represented by 'mihi' ('I') or 'illi' ('he'), so called 'near' each other), line 11. On the other hand, with 'vicinus Novio vel inquilinus sit,/si quis Novium videre non vult' (lines 12 and 13), the poet suggests that near $=$ far, i.e. the nearer you are to Novius the further away you are from him: so a, i.e. 'prope' (hinted at by 'vicinus', 'inquilinus') = b, i.e. 'procul' (suggested by 'videre non vult'), lines $12-13$.

Therefore,

$$
\begin{aligned}
& \mathrm{a}=\mathrm{b}(\text { line } 10), \\
& \mathrm{b}=\mathrm{a}(\text { line } 11),
\end{aligned}
$$

and $a=b$ (lines 12 and 13 ).

The semantic content of the spatial concepts nearness and remoteness, is determined by the ingenious and selective employment of pattern and opposition. The binary opposition near-far, in the hands of the poet, confers on both spatial relations an exceptional and surprising meaning: the fact that you can be an inmate of Novius and nevertheless be far away from him, as well as the 'solution' that one must move further away from him in order to be near him. The conclusion is apparently in conflict with the traditional conception that far is far, and near is near. In the light of the poet's handling of space it is, however, a seemingly absurd though really well-founded statement: if you don't wish to see Novius, you must become his neighbour, or worse even, his fellow-tenant: a pointed conjunction of apparent contra- 
dictions, i.e. an oxymoron. Accordingly the spatial scope or frame here functions symbolically in a very powerful way: Novius' nearness symbolizes, with a very effective tinge of irony and humor, his actual inaccessibility. Consequently space is here implemented metaphorically. The physical space is abstracted to a psychological space. The way in which this depicted space is arranged, is nothing but a dexterous play with a spatial paradox, by means of which the above-mentioned message of Novius' inaccessibility is forcefully and strikingly conveyed (Cloete et al., 1985:169; Cloete, 1982:26,46-47).

Finally, the presentation of space in a given text, as for example in this poem, is also related to the narrator's point of view, i.e. the person or persons from whose spatial consciousness and perspective the observation and focalization take place. ${ }^{5}$ Focalization is therefore vested in the person who reports what he observes (Cloete et al., 1985:76). Focalization can be external or internal according to whether the focalizer is external or internal in relation to the world presented in the text. Since the speaker in 1.86 is also actor or participant in the situation he describes (Van Luxemburg et al., 1983:169) ${ }^{6}$, we are consequently dealing with an internal focalizer. The reader sees as it were, through the eyes of, and from the same angle as that of the speaker, how near the speaker is to his neighbour, so near that if from his 'cenaculum's' ('upper room's) window he stretches his arm out to his neighbour, Novius, he can actually touch him (Van Luxemburg et al., 1983:175-178; Bal, 1978:104-108; Cloete et al., 1985:75-78).

It is quite obvious from our text that the spatial perspective is based on the binary oppositions of here (i.e. 'de nostris ... fenestris' ('from my window(s)') and there (i.e. (i) 'vicinus' ('neighbour'), and (ii) 'Syene on the Nile' = Egypt) (Zoran, 1984:322).

In this internal perception of space in the poem four sense organs are involved: the tactile sense, i.e. the hand ('manuque . . tangi', line 1), taste ('convivere', 'feast with', line 8), the faculty of vision, i.e. the eye, which is thé organ for experiencing space ('videre', line 8) (Fowler, 1984:184; Cloete et al., 1985:168), and hearing ('audire', line 9), i.e. the ear. Although perception in which the sense of touch is involved usually has little spatial significance (Bal, 1978:98; Van Luxemburg et al., 1983:189), it is, however, of paramount importance in the light of the spatial context in this poem, and very strongly points to spatial adjacency. The fact that Novius cannot be perceived (visually) suggests that the space, i.e. distance, between him and the poet is too great. Because the sound of Novius' voice is not audible, it

5. Cf. Cloete et al., 1985:96; Blok, 1960:233-234; Cloete, 1982:39-40; Bal, 1978:104, 106; Zoran, 1984:323-327. Mieke Bal regards the relation between the elements of the 'story' and the 'vision' from which they are presented as focalization ('focalisatie'), while Zoran defines it as 'a field of vision'. The subject of focalization, i.e. the focalizer, is the point from which the space (or distance) between the speaker and Novius is seen.

6. There is no need to take epigram 1.86 as autobiographical. 
likewise contributes to the conception and imagination of space and distance. Novius is therefore, as far as the physical as well as psychological space are concerned, at a great distance. With the aid of the above-mentioned sense organs the relation between the persons, (i.e. the speaker (poet), Novius and Terentianus), and space is created.

\section{Conclusion:}

Space is the predominant theme in epigram 1.86 (Van Luxemburg et al., $1985: 19())$. It is clear that space in this particular poem could not remain unnoticed, and that it becomes thematized, in other words, it is made the object of presentation per se. Moreover, space in 1.86 must be termed lyric space, because it is not characterized by movement in space, as opposed to epic space, the latter of which contains movement defined by persons, events and time. In other words, lyric space here in 1.86, is nothing but 'frozen' or static space, which forms the basis of letting the reader 'see' one situation, i.e. grasping a particular image which gives the reader a specific perspective of this space (Maatje, 1974:172-173; Bal, 1978:100; Venter, 1985:21). In addition to this, space also performs an important function in the thematic construction of the poem (Van Luxemburg et al., 1983:231). Furthermore, space in 1.86 can be termed a fundamental, communicative structural category (Cloete $e t$ al., 1985:95; Venter, 1985:19, 22). This delightful little poem is an excellent example of how space as a category can be a special implement in the hands of a poet.

One can say in conclusion that in Martial 1.86 especially, space is not only very effectively utilized in sharpening and intensifying the poignancy of the final and surprising solution, but that it is also metaphorically implemented. Space in this epigram can therefore also be termed a figurative or conceptual manifestation (Cloete, 1982:35).

Space can be regarded as a means to a certain end (Zoran, 1984:333). It may be exploited in different ways in a text, and can convey meaning through guiding the reader to a better understanding of the poem (Venter, 1985: 19-20). Finally it seems justified to infer that the use of space, and in particular lyric space with its specific perspective, increases the forcefulness of the message conveyed.

\section{Bibliography}

Bal, Mieke. 1978. De theorie van vertellen en verhalen. Muiderberg: Dick Coutinho.

Blok, W. 1960. Verhaal en lezer. Groningen: J.B. Wolters.

Cloete, T.T. 1982. Hoe om 'n gedig te ontleed. Pretoria: Academica.

Cloete, T.T. et al. 1985. Gids by die literatuurstudie. Pretoria: HAUM.

Fowler, H.W. 1984. A Dictionary of Modern English Usage. Hertfordshire: Omega Books.

Howell, Peter. 1980. A Commentary on Book One of the Epigrams of Martial. London: The Athlone Press.

Lotman, J.M. 1972. Die Struktur literarischer Texte. München: Fink. 
Maatje, Frank C. 1974. Literatuurwetenschap. Utrecht: Oosthoek's Uitgeversmaatschappij. Perry, M. and Sternberg, M. 1986. The King through ironic eyes. Poetics Today, $7(3), 275-283$.

Sternberg. M. 1985. The Poetics of Biblical Narrative. Bloomington: Indiana University Press.

Van Luxemburg, J. et al. 1983. Inleiding in de literatuurwetenschap. Muiderberg: Dick Coutinho.

Venter, L.S. 1985. Narratiewe ruimtes. Tydskrif vir Geesteswetenskappe, 25(1), 19-29.

Zoran, Gabriel. 1984. Towards a theory of space in narrative. Poetics Today, 5(2)309-335. 